\title{
Evaluation of Antioxidant Capacity in Advanced Non-Small Cell Lung Cancer
}

\section{İleri Evre Küçük Hücre Dışı Akciğer Kanserlerinde Antioksidan Kapasitenin Değerlendirilmesi}

\author{
Mutlu Hızal $^{1}$, Mehmet Ali Sendur ${ }^{1}$, Burak Bilgin ${ }^{1}$, Gözde Kart Bayram², Doğan \\ Bayram $^{2}$, Muhammed Bulent Akınc ${ }^{1}$, Didem Sener Dede ${ }^{1}$, Salim Neselioglu ${ }^{3}$, Ozcan \\ Erel $^{3}$, Bülent Yalcin ${ }^{1}$

\footnotetext{
${ }^{1}$ Yıldırım Beyazıt Üniversitesi Tıp Fakültesi, Tıbbi Onkoloji Bilim Dalı, Ankara
} \\ ${ }^{2}$ Yıldırım Beyazıt Üniversitesi Tıp Fakültesi, İç Hastalıkları Anabilim Dalı, Ankara \\ ${ }^{3}$ Yıldırım Beyazıt Üniversitesi Tıp Fakültesi, Tıbbi Biyokimya Anabilim Dalı, Ankara
}

\section{ÖZET}

GİRIŞ ve AMAÇ: Akciğer kanseri, 2018 yılı verilerine göre tüm dünyada iki milyonun üstünde yeni vakayla en s1k görülen kanser tipidir ve kansere bağlı ölümlerin \%18,4'ünü oluşturur. Oksidatif stres, karsinogenezin tüm basamaklarında rol oynayabilir. Bu çalışmada, KHDAK hastalarında tanı anında antioksidan kapasitenin bir göstergesi sayılabilecek tiyol-disülfit dengesinin değerlendirilmesi ve sağlıklı kontrollerle karşılaştırılması amaçlanmıştır.

YÖNTEM ve GEREÇLER: Yeni tanı ileri evre KHDAK olan 43 hasta ve hasta grubuyla yaş ve cinsiyet açısından uyumlu 50 sağlıklı kontrol çalışmaya dahil edildi. Hastaların tiyol-disülfit homeostaz analizi için gerekli olan kan örnekleri tanı anında elde edildi. Hasta ve kontrol grubunun serum tiyol ve disülfit örnekleri otomatik spektrofotometrik metod ile ölçüldü. Hastaların klinik, radyolojik ve laboratuvar özellikleri kaydedildi. BULGULAR: Doğal tiyol ve toplam tiyol değerlerinin hasta grubunda kontrol grubuna kıyasla anlamlı şekilde düşük olduğu gösterildi $(\mathrm{p}<0,001)$. Disülfit düzeyleri ve antioksidan kapasite göstergelerinden disülfit / doğal tiyol oranı açısından gruplar arasında anlamlı fark saptanmadı. Ortanca genel sağkalım 9,1 ay (1,2 - 37,9 ay) olarak tespit edildi. Tiyol ve disülfit değerlerinin sağkalım üzerine etkisi saptanmadı.

TARTIŞMA ve SONUÇ: Non-enzimatik antioksidan bileşiklerin başında gelen tiyol bileşiklerinin hasta grubundaki düşük seviyeleri KHDAK patogenezinde üretimi artan ROS'nin eliminasyonu için gösterilen artmış kullanıma bağlı olabilir. Süreç içerisinde miktarı azalan antioksidan tiyol bileşikleri aynı zamanda ROS artışının hem nedeni hem sonucu olabilir. Disülfit değerlerinin artmaması artmış hücre döngüsüyle ilişkilendirilebilir.

Anahtar Kelimeler: tiyol, disülfit, antioksidan, akciğer kanseri

\section{ABSTRACT}

INTRODUCTION: According to 2018 data, lung cancer is the most common cancer type with more than two million new cases worldwide and responsible for $18.4 \%$ of cancer-related deaths. Oxidative stress have a major role in every steps of carcinogenesis. In this study, we aimed to evaluate the thiol-disulfide balance, which can be considered as an indicator of antioxidant capacity, in NSCLC patients and to compare it with healthy controls. METHODS: 43 patients with advanced NSCLC and 50 healthy controls enrolled to study. Blood samples for the analysis of thiol-disulfide homeostasis were obtained at the time of diagnosis in patient group. Serum thiol and disulfide samples of the patient and control groups were measured by automatic spectrophotometric method. Clinical, radiological and laboratory features of the patients were recorded.

RESULTS: Natural thiol and total thiol levels were significantly lower in the patient group compared to the control group $(\mathrm{p}<0.001)$. There was no significant difference between the groups in terms of disulfide levels and disulfide / natural thiol ratio which was an indicator of antioxidant capacity. Median overall survival was determined to be 9.1 months (1.2 - 37.9 months). Thiol and disulfide levels had not an effect on survival, significantly. 
DISCUSSION AND CONCLUSION: Lower thiol level in patient group might be due to the increased usage for the elimination of ROS which contributes NSCLC pathogenesis. The amount of antioxidant thiol compounds that decrease in the process could be both the cause and the result of the ROS increase. The reason for disulfide values not increasing may be related to increased cell cycle.

Keywords: thiol, disulfide, antioxidant, lung cancer

\section{GİRIS}

Akciğer kanseri, 2018 y1lı verilerine göre tüm dünyada iki milyonun üstünde yeni vakayla en sı görülen kanser tipi ve kansere bağl1 ölümlerin \%18,4'ünü oluşturarak önemli bir sağlik sorunu olmaya devam etmektedir (1). Küçük hücre dişı akciğer kanserleri (KHDAK) tüm akciğer kanserlerinin yaklaşık $\% 85$ 'ini oluşturmaktadır. Adenokanserler \%40 ve Skuamöz hücreli kanserler ise \%25-30 ile akciğer kanserlerinin en sik görülen iki histolojik alt tipidir (2).

Oksidatif stres, başlangıç ve promosyon aşamaları dahil karsinogenezin tüm basamaklarında rol oynayabilir ve hastalığın progresyonuna neden olabilir (3). Reaktif oksijen türleri (ROS), hücre içi başlıca kaynağ1 olan mitokondri ve diğer enzim sistemleri (NADPH oksidaz, Sitokrom P450, Aldehit oksidaz, Nitrik oksit sentaz vs.) tarafindan hücre metabolizmasının doğal ürünleri olarak ortaya çıkabilirler. Ayrıca sigara gibi çevresel toksinlere, inflamasyona, artmış sitokin sentezine, büyüme faktörlerine, kemoterapi ve radyoterapi gibi sitotoksik tedavilere yanıt olarak da meydana gelebilirler $(4,5)$.

Fizyolojik koşullar altında, meydana gelen ROS farklı enzimatik ve non-enzimatik antioksidan sistemler tarafindan dengelenirler (6). Ancak bu sistemlerin kapasitesinin aşılması, etkisiz hale getirilemeyen ROS'nin oksidatif stres denilen tabloya yol açmasına neden olur. Antioksidan enzimleri başlıca Süperoksit dismutaz, Katalaz ve Glutatyon peroksidaz oluştururken; non-enzimatik antioksidanların başında sülfidril grubu içeren tiyol bileşikleri gelir (7).

Tiyol grupları, ROS'nin nötralize edilmesinde rol oynayan oldukça güçlü antioksidanlardır. Oksidasyon reaksiyonlarına giren tiyol grupları, disülfit (DS) bağları kurarlar ve bu DS bağları sonrasında normal fizyolojik koşullar altında yeniden tiyol gruplarına indirgenebilirler (7). Antioksidan kapasitenin bir göstergesi sayllabilecek tiyol ve DS grupları arasındaki bu karşılıklı etkileşim ve dönüşüm hücre sinyal mekanizmaları, apoptosis, protein sentezi gibi hücre için hayati fonksiyonlara sahip yolakları kapsamlı şekilde etkileyebilir (8). Dinamik tiyol-disülfit dengesinin bozulmasının birçok kronik hastalığın ve akciğer kanseri de dahil olmak üzere farklı kanser tiplerinin patogenezinde rol oynayabileceği gösterilmiştir (9-11).

$\mathrm{Bu}$ çalışmada, KHDAK hastalarında tanı anında antioksidan kapasitenin bir göstergesi say1labilecek tiyol-disülfit dengesinin değerlendirilmesi ve sağlıklı kontrollerle karşılaştırılması amaçlanmıştır.

\section{GEREÇ ve YÖNTEM}

2015-2016 y1llarında Ankara Y1ldırım Beyazıt Üniversitesi Tıbbi Onkoloji bilim dalındatakibe giren, daha önce tedavi almamış, yeni tanı ileri evre KHDAK olan 43 hasta ve hasta grubuyla yaş ve cinsiyet açısından uyumlu 50sağlıklı kontrol 2017 y1lında çalışmaya dahil edildi. Hastalar 18 yaşın üstündeydi ve KHDAK tanisı patolojik olarak doğrulanmıştı. Küçük hücre dışı akciğer kanserleri evrelemesi için Amerikan Ortak Kanser Komitesi (AJCC) 7. baskısı kullanıldı. Lokal ileri evre ve metastatik hastalar çalışmaya dahil edildi. Erken evre hastalar, böbrek yetmezliği, karaciğer yetmezliği, aktif inflamasyon veya enfeksiyonu olan hastalar çalışmadan dışlandı. Ayrıca hedef tedaviye uygun EGFR, ALK veya ROS mutasyonu olduğu bilinen hastalar çalışmadan dışlandı. Hastaların klinik, radyolojik ve laboratuvar özellikleri kaydedildi. Sigarayı bırakmış olarak sınıflandırılabilmek için bıraktıktan sonra en az 6 aydır hiç sigara içmemiş olmak kriter kabul edildi.

Hastaların tiyol-disülfit homeostaz analizi için gerekli olan kan örnekleri tanı anında rutin kan testleri için perifer venöz yolla örnek alınırken elde edildi ve bu yüzden hastalara ek girişim uygulanmadi. Gerek kontrol gerekse hastaların kan örnekleri sabah saatlerinde elde edildi ve $1500 \mathrm{~g}$ ile 10 dakika boyunca santrifüj edilerek ayrilan serum örnekleri $\quad-80 \quad \mathrm{C}$ sicaklıkta analize kadar bekletildi.

Serum tiyol ve DS örnekleri Erel ve Neşelioğlu tarafından geliştirilen otomatik 
spektrofotometrik metod ile ölçüldü (12). Buna göre dinamik DS bağlarını fonksiyonel serbest tiyol gruplarına indirgemek için sodyum borohidrit kullanıldı. İndirgenmiş sodyum borohidritin, ditiyonit-2 nitrobenzoik bileşiğine indirgenmesini önlemek için NaBH4, formaldehit ile ortamdan uzaklaştırıldı. Ditiyonit-2 nitrobenzoik ile reaksiyondan sonra doğal tiyol (DT) ve toplam tiyol (TT) seviyeleri ölçüldü. Doğal tiyol miktarının, TT içeriğinden çıkarılmasıyla elde edilen sonucun farkının yarısı DS seviyesini gösterdi. Tiyoldisülfit homeostazının yani antioksidan kapasitenin göstergesi için en iyi belirteç olan Disülfit / Doğal tiyol (DS / DT) oran1 hesaplandi.

Analizler IBM SPSS Statistics 22.0 (SPSS Inc, Chicago, IL, USA) istatistik analiz paket programında yapıldı. Sürekli değişkenler ortalama, standart sapma, minimum, maksimum değerleri ile birlikte kategorik değişkenler; frekans tabloları ve yüzdeleri ile verildi. Kategorik değişkenler çapraz tablolarda Pearson Ki-kare veya Fischer Exact testi kullanılarak karşılaştırıldı. Sağ kalım analizleri Kaplan-Meier metodu ile değerlendirildi. Sayısal değişkenlerin kıyaslanması için normal dağılıma uyması halinde Bağımsız Örneklem T Testi, uymaması halinde Mann-Whitney U Testleri kullanıldı. İstatistiksel anlamlılık için $\mathrm{p}<0,05$ değeri kriter olarak kabul edildi.

Üniversitenin Klinik Araştırmalar Etik Kurulu'ndan onay alındı.(14.06.2017, No:126)

\section{SONUÇLAR}

\section{Hasta Özellikleri}

Çalışmaya toplam 43 hasta ve 50 sağlıklı kontrol dahil edildi. Hasta grubu 3 kadın ve 40 erkek, kontrol grubu ise 3 kadın ve 47 erkek katılımcıdan oluşuyordu. Hasta grubunun ortanca yaş1 60 (23-78), kontrol grubunun ise ortanca yaşı 60,5 (38-78) olarak bulundu. Hasta ve kontrol grubu arasında yaş ve cinsiyet açısından anlamlı fark yoktu. Hastaların \%98'inin hayat boyu sigara maruziyeti mevcuttu. Özellikle tanı anında aktif olarak sigara içenlerin oranının \%77'ye ulaştığ1 görüldü.

Hasta grubunun
özellikleri
incelendiğinde $\% 56$ 'sının en az bir komorbiditesi olduğu, \%61 ile büyük kısmının hastalığının adenokanser alt tipinde olduğu, 6 hastanın lokal ileri (evre IIIB ve üstü) evrede olduğu, en s1k metastaz bölgelerinin ise kemik, karaciğer ve beyin olduğu görüldü (Tablo.1). Ayrıca çalışmaya alınan bir hastada sonradan pozitif olduğu anlaşılan EGFR ekzon 21 mutasyonu mevcuttu. Dokuz hastada (\%21) kemoradyoterapi tedavisiyle başlanırken, birinci basamak kemoterapi alan hastaların $(\mathrm{n}=37)$ tedavi protokollerininin \%51'ini platin ve pemetrekset kombinasyonu, \%22'sini platin ve taksan kombinasyonu ve \%13'ünü platin ve gemsitabin kombinasyonu oluşturmaktayd.

\section{Antioksidan}

\section{Değerlendirilmesi}

Kapasitenin

Hastaların tanı anında elde edilen doğal tiyol, toplam tiyol ve disülfit ortanca değerleri surasiyla 358,398 ve $20,9 \mu \mathrm{mol} / \mathrm{L}$ olarak saptand1. Kontrol grubu için bu ortanca değerler sirasıyla 429,464 ve $20 \mu \mathrm{mol} / \mathrm{L}$ olarak bulundu. Gerek doğal tiyol gerek toplam tiyol değerlerinin hastalarda anlamlı şekilde düşük olduğu gösterildi $(\mathrm{p}<0,001)$.

Disülfit düzeyleri açısından gruplar arasında anlamlı fark saptanmadı. Disülfit düzeyleriyle doğrudan bağlantılı olarak antioksidan kapasitenin göstergelerinden olan DS/DT oranları bakımından gruplar arasındaki fark istatistiksel anlamlılığa ulaşmadı $(\mathrm{p}=0,08)$.

\section{Kapasite}

Genel Sağkalım ve Antioksidan

Ölen 42 hastaya (\%98) karşıllk hastaların sadece bir tanesi yaşamını sürdürüyordu. Ortanca genel sağkalım 9,1 ay (1,2 - 37,9 ay) olarak tespit edildi (Şekil 1). Hastalar DT, TT, DS ve DS/DT oranlarının ortanca değerleri üzerinden düşük ve yüksek olarak ikiye ayrılarak karşılaştırıldıklarında herhangi bir değişken için sağkalım açısından düşük ve yüksek gruplar arasında anlamlı fark saptanmadi. 
Tablo 1. Hastaların Demografik ve Klinik Özellikleri

\begin{tabular}{|c|c|c|c|}
\hline Değişken & Değer (n, \%) & Değgişken & Değer (n, \%) \\
\hline $\begin{array}{l}\text { Yaş } \\
\text { Ortanca (min-maks.) }\end{array}$ & $60(23-78)$ & $\begin{array}{l}\text { Evre } \\
\text { Lokal İleri } \\
\text { Metastatik }\end{array}$ & $\begin{array}{l}6(\% 14) \\
37(\% 86)\end{array}$ \\
\hline $\begin{array}{l}\text { Cinsiyet } \\
\text { Kadin } \\
\text { Erkek }\end{array}$ & $\begin{array}{l}3(\% 7) \\
40(\% 93)\end{array}$ & $\begin{array}{l}\text { Metastaz Bölgeleri } \\
\text { SSS } \\
\text { Karaciğer } \\
\text { Sürrenal } \\
\text { Kemik } \\
\end{array}$ & $\begin{array}{l}12(\% 28) \\
12(\% 28) \\
9 \quad(\% 21) \\
13(\% 30) \\
\end{array}$ \\
\hline $\begin{array}{l}\text { Komorbiditeler } \\
\text { Diyabet } \\
\text { Hipertansiyon } \\
\text { KOAH } \\
\text { KAH } \\
\end{array}$ & $\begin{array}{l}8(\% 19) \\
9(\% 19) \\
7(\% 16) \\
6(\% 14)\end{array}$ & $\begin{array}{l}\text { Sigara Öyküsü } \\
\text { Aktif içiyor } \\
\text { Bırakmış } \\
\text { Hiç içmemiş }\end{array}$ & $\begin{array}{ll}33 & (\% 77) \\
8 & (\% 19) \\
2 & (\% 4)\end{array}$ \\
\hline $\begin{array}{l}\text { Histolojik Alt Tip } \\
\text { Adenokanser } \\
\text { Skuamöz hücreli } \\
\text { NOS } \\
\end{array}$ & $\begin{array}{l}26(\% 61) \\
13(\% 30) \\
4 \quad(\% 9) \\
\end{array}$ & $\begin{array}{l}\text { 1.Basamak Tedavi } \\
\text { Kemoradyoterapi } \\
\text { Kemoterapi }\end{array}$ & $\begin{array}{l}9(\% 21) \\
37(\% 86)\end{array}$ \\
\hline
\end{tabular}

Tablo 2. Hasta ve Kontrol Grubunun Tiyol ve Disülfit Değerleri

\begin{tabular}{|l|c|c|}
\hline Değişken & Hasta Grubu & KontrolGrubu \\
& Ortanca (min-maks) & Ortanca (min-maks) \\
\hline DoğalTiyol $(\mu \mathrm{mol} / \mathrm{L})$ & $358(216-3261)$ & $429(313-607)$ \\
\hline Disülfit $(\mu \mathrm{mol} / \mathrm{L})$ & $20,9(0,05-55)$ & $20,0(8,4-37)$ \\
\hline ToplamTiyol $(\mu \mathrm{mol} / \mathrm{L})$ & $398(253-573)$ & $464(354-632)$ \\
\hline Disülfit / DoğalTiyol & $0,059(0,01-0,19)$ & 0,98 \\
\hline
\end{tabular}

Şekil 1. Hastaların Genel Sağkalım Analizi

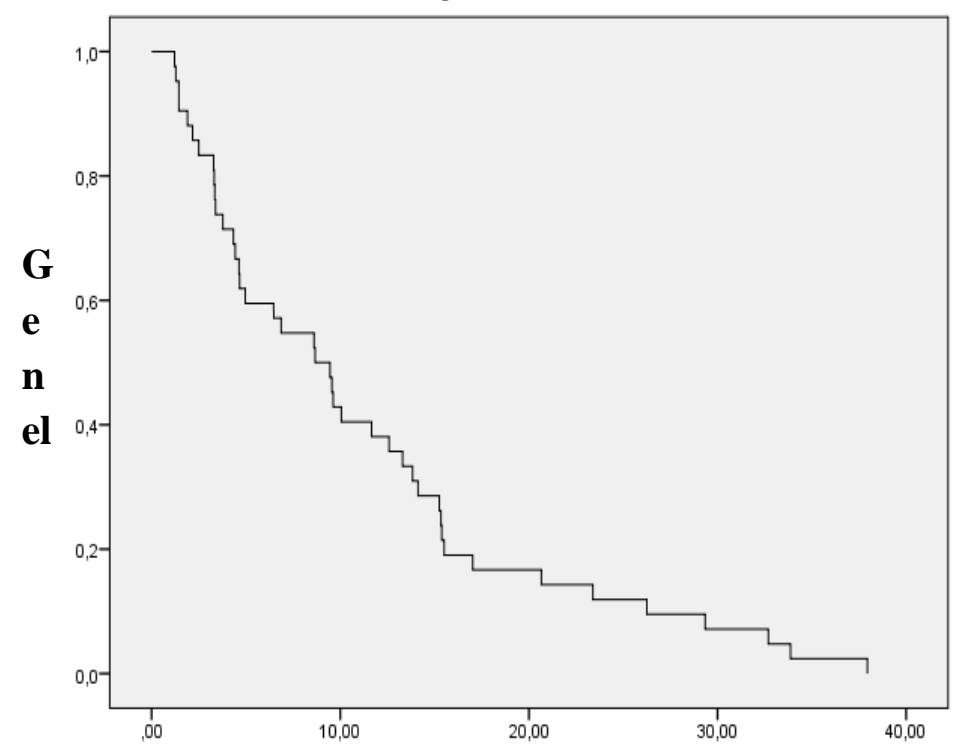

\section{Zaman}




\section{TARTIŞMA}

$\mathrm{Bu}$ çalışmayla ileri evre KHDAK hastalarında tanı anında tiyol değerlerinin normal populasyona kıyasla anlamlı şekilde düşük olduğunu gösterdik. Ancak disülfit değerlerinde anlamlı farklılık saptanmadi. Bununla beraber, hasta ve kontrol gruplar1 arasındaki disülfit değerlerinde farkl1lık olmamasıyla doğrudan ilişkili olarak antioksidan kapasitenin göstergesi DS/DT oranındaki değişiklik istatistiksel anlamlılığa ulaşmadi.

Farklı kanser türleri arasında KHDAK, oksidatif stresin patogeneze katkısı en çok araştırılmış kanser alt tiplerinin başında gelir. Antioksidan-oksidan dengesinin oksidan lehine bozulduğu her durumu ifade etmek için kullanılan bu durum yaşlanma, kronik hastalıklar, dejeneratif hastalıklar ve kanser gibi birçok olgunun patogenezine katkıda bulunabilir (5).

Tartışmanın anlam kazanabilmesi için en başından vurgulamak gerekir ki oksidatif stresin bir çatı kavram olarak kapsayıcılığı artıkça, farklı hastalıkların patogenezine yaptığı niteliksel ve niceliksel katkıyı objektif ve standardize edilmiş olarak ölçümlemek zorlaşmaktadır. Kanserin tek bir hastalık olarak düşünülemeyeceği gerçeği üzerinden dekatlar geçmesi bir yana; bir kanser alt tipi olan KHDAK halihazırda oldukça heterojen moleküler alt gruplara sahip, farklı patogenetik yolaklardan köken alabilen geniş bir çalışma sahasıdır (13). Diğer taraftan moleküler düzeyde yapılan çalışmalarla KHDAK patogenezindeki rolü keşfedilen oksidatif stresle ilişkili sayısız molekül ve/veya yolakların her birinin hastalığın oluşumu ve gelişimine klinik anlamda ne kadar katk1 yaptıkları ayrı bir tartışma konusu oluşturmaktadır (14).

Çalışmamızda hasta grubunda tiyol değerlerinin kontrol grubuna göre düşük olması hem bir neden hem de bir sonuç olarak ele alınabilir. Hücre içi temel ROS kaynağ aerobik solunumun merkezi organeli konumundaki mitokondridir. Bununla beraber diğer intrinsik ROS üreten kaynaklar arasında NADPH oksidaz,Sitokrom P450, Aldehit oksidaz, Nitrik oksit sentaz gibi enzimatik sistemler yer alır (4). Sadece doğal intrinsik kaynakları olmayan ROS, aynı zamanda akciğer kanserinin etiyolojisinde ve patogenezinde yer alan sigara, çevresel toksinler, inflamasyon, artmış sitokin sentezi ve büyüme faktörlerine bağlı olarak da artış gösterebilir. Antioksidan sistemleriyle elimine edilmemiş ROS artışının yarattığı oksidatif stres DNA hasarına katkıda bulunabilir. Oksidatif DNA hasarı tek veya çift-iplik kırıklarına, baz modifikasyonlarına, çapraz bağ oluşumlarına, transkripsiyon uyarılmasına, replikasyon hatalarına kadar uzanan ve genomik instabiliteye yol açan birçok duruma neden olarak küçük hücre-dışı akciğer karsinogenezine katkida bulunabilir (14). Ayrıca ROS'nin birincil sonuçlarından lipid peroksidasyonu ve son ürünlerinin artış1, bununla beraber reaktif nitrojen türlerinin KHDAK patogenezindeki yeri önceki çalışmalarla gösterilmiştir $(15,16)$.

Bu ROS'ni dengelemek, elimine etmek ve vereceği zararı azaltabilmek için kullandığımız enzimatik sistemlerin (Süperoksit dismutaz, Katalaz ve Glutatyon peroksidaz vb.) yanısıra non-enzimatik antioksidan bileşikler mevcuttur $(7,17)$. Nonenzimatik antioksidan bileşiklerin başında gelen tiyol bileşiklerinin hasta grubundaki düşük seviyeleri KHDAK patogenezinde üretimi artan ROS'nin eliminasyonu için gösterilen artmış kullanıma bağlı olabilir. Süreç içerisinde miktarı azalan antioksidan tiyol bileşikleri aynı zamanda ROS artışının hem nedeni hem sonucu olabilir.

Bir diğer göz önünde bulundurulmas1 gereken faktör hasta grubunun \% 77'sinin aktif olarak sigara içiyor olmasıdır. Sigaranın birçok antioksidanın düzeyini düşürdüğü önceki çalışmalarda gösterilmiştir (18). Akciğerler söz konusu olduğunda sigara sistemik etkisinin yanısıra doğrudan epitel hasarıyla akciğerlerde oksidatif strese neden olmaktadır (19). Sigaranın KHDAK etiyolojisindeki bir numaralı risk faktörü olması, ayrıca yarattı̆g1 oksidatif stresin de DNA'da kovalent bağlar oluşumuna ve DNA kırıklarına yol açarak yine akciğer kanseri patogenezine katkıda bulunması hasta grubundaki tiyol düşüklüğünü hem bir neden hem de bir sonuç olarak açıklamaya katkıda bulunabilir (19).

Literatürde benzer bir hasta grubuyla yapılan ve 2015 'te yayınlanan başka bir çalışmada, sonuçlarımıza benzer şekilde ileri evre KHDAK hastalarının $(n=35)$, kontrol grubuna göre tanı anında anlamlı şekilde düşük 
tiyol seviyelerine sahip oldukları gösterilmiştir (10). Bu çalışmada ayrıca DT değerlerinin genel sağkalımla (OS) korelasyon gösterdiği bulunmuştu. Çalışmamızda ise tiyol değerleriyle OS arasında korelasyon gösterilmedi. İki çalışma arasında hasta grupları arasındaki en belirgin fark ise adenokarsinom alt tipinin çalışmamızda \%61, diğer çalışmada ise $\% 25$ oranında bulunmasıydı (10).

Küçük hücreli akciğer kanserlerinin (\%22) de dahil edildiği ve hastaların \%86'sının evre 3B-4 olduğu, 50 hasta içeren bir başka çalışmanın bulguları sonuçlarımızla benzerlik göstermektedir (20). Bu çalışmada da DT ve TT seviyeleri hasta grubunda anlamlı şekilde düşük gösterilmiş ancak tıpkı çalışmamızdaki gibi disülfit değerlerinde anlamlı fark saptanmamış ve gerek OS gerekse diğer klinik parametrelerle anlamlı ilişki saptanamamıştır (20).

Çalışmamızda disülfit değerlerinde anlamlı farkl111k saptanmad1, hatta ortanca değerler hasta ve kontrol grubu arasında oldukça benzerdi. Oksidanların tiyol gruplarıla etkisiz hale getirildiği reaksiyonlarda tiyol grupları kovalent bağlarla disülfit gruplarına dönüşürler. Fizyolojik koşullar sağlandığında ise disülfit grupları yeniden tiyol gruplarına dönüşebilir. Oksidan maruziyetinin arttığı diyabet, obezite gibi hastalıklarda tiyol gruplarının disülfite doğru kayması önceki çalışmalarda gösterilmiştir (21, 22). Oksidatif stres altında olan ve tiyol gruplarının azaldığı KHDAK hastalarında da disülfit miktarının artması beklenebilir. Bununla birlikte, multipl myelom gibi proliferatif hastaliklarda veya renal hücreli karsinom, mesane kanseri, kolon kanseri gibi soliter malignitelerde disülfit değerlerinin normal populasyona kıyasla düşük olduğu gösterilmiştir (12). Bizim çalışmamızda da KHDAK hastalarında disülfit değerleri normal populasyonla aynı değerlerde bulunmuştur. Tıpk1 diğer kanser tiplerinde olduğu gibi değerin kontrol grubuna göre yüksek bulunmamış olması artmış hücre döngüsüyle ilişkilendirilebilir. Bir gelecek perspektifi olarak disülfit değerlerinin birçok kanserde sağlıklı kontrollere kıyasla normal, hatta düşük bulunuyor oluşu disülfit değerleri için malignbenign durumlar arasında bir ayrıma gidilmesi gerekliliğini önümüze koymaktadır. Yine antioksidan kapasitenin göstergelerinden sayılan ve disülfit değerlerinin doğrudan belirleyicilerinden olduğu DS/DT oranı da malign hastalıklar için ayrı bir şekilde refere edilebilir.

Çalışmamıza alınan hastaların ileri evre, büyük bir kısmının ise metastatik oluşu, tümör yükünün fazla olması sonuca katkıda bulunan diğer faktörler olabilir. Bununla doğrudan ilişkili olarak bu gerçek yaşam hastalarının performans, yaş ve komorbiditelerine bakılmaksızın çalışmaya dahil edilmesi aynı zamanda randomize kontrollü çalışmalara kıyasla daha kısa sayılabilecek ortanca 9,1 aylik genel sağkalımın da nedenini oluşturmaktadır. Ayrıca sonuçlar değerlendirilirken hasta grubunun diyabet, hipertansiyon, kronik obstruktif akciğer hastalığı ve koroner arter hastalığı gibi hemen hepsi antioksidan kapasitenin tüm göstergelerini etkileme potansiyeli içeren komorbiditelere sahip olduğu mutlaka göz önünde bulundurulmalıdır (21, 23-25).

Daha ötesi oldukça karmaşık patogenetik yolakların hakim olabildiği böylesine heterojen bir hastal1kta gerek tiyol değerlerinin neden-sonuç ilişkisi içinde anlamlandırılabilmesi gerekse disülfit değerlerinin kontrol grubuyla benzer olarak bulunması, kesitsel olarak tanı anı değerlerini inceleyen çalışmamızın sınırlarını da belirlemektedir.

Oksidan-antioksidan dengesini oluşturan farklı yolakların ve bileşiklerin keşfi ve bu yolakları ve birbirleriyle ilişkilerini düzenleyen genomik değişikliklerin daha iyi aydınlatılması hedeflenmiş ajanlar başta olmak üzere yeni tedavi yöntemlerinin geliştirilmesine ön ayak oluşturabilir (14).

Çıkar Çatışması

Yazarların çıkar çatışması

bulunmamaktadır.

\section{REFERANSLAR}

1.Bray F, Ferlay J, Soerjomataram I, Siegel RL, Torre LA, Jemal A. Global cancer statistics 2018: GLOBOCAN estimates of incidence and mortality worldwide for 36 cancers in 185 countries. CA Cancer J Clin. 2018;68(6):394-424.

2.Duma N, Santana-Davila R, Molina JR. Non-Small Cell Lung Cancer: Epidemiology, Screening, Diagnosis, and Treatment. Mayo Clin Proc. 2019;94(8):1623-40. 
3.Masri F. Role of nitric oxide and its metabolites as potential markers in lung cancer. Ann Thorac Med. 2010;5(3):123-7.

4.Finaud J, Lac G, Filaire E. Oxidative stress : relationship with exercise and training. Sports Med. 2006;36(4):327-58.

5.Filaire E, Dupuis C, Galvaing G, Aubreton S, Laurent $\mathrm{H}$, Richard R, et al. Lung cancer: what are the links with oxidative stress, physical activity and nutrition. Lung Cancer. 2013;82(3):383-9.

6.Lawless MW, O'Byrne KJ, Gray SG. Oxidative stress induced lung cancer and COPD: opportunities for epigenetic therapy. J Cell Mol Med. 2009;13(9A):280021.

7.Circu ML, Aw TY. Reactive oxygen species, cellular redox systems, and apoptosis. Free Radic Biol Med. 2010;48(6):749-62.

8.Biswas S, Chida AS, Rahman I. Redox modifications of protein-thiols: emerging roles in cell signaling. Biochem Pharmacol. 2006;71(5):551-64.

9.Hanikoglu F, Hanikoglu A, Kucuksayan E, Alisik M, Gocener AA, Erel O, et al. Dynamic thiol/disulphide homeostasis before and after radical prostatectomy in patients with prostate cancer. Free Radic Res. 2016;50(sup1):S79-S84.

10.Dirican N, Dirican A, Sen O, Aynali A, Atalay S, Bircan HA, et al. Thiol/disulfide homeostasis: A prognostic biomarker for patients with advanced nonsmall cell lung cancer? Redox Rep. 2016;21(5):197-203. 11.Eryilmaz MA, Kozanhan B, Solak I, Cetinkaya CD, Neselioglu S, Erel O. Thiol-disulfide homeostasis in breast cancer patients. J Cancer Res Ther. 2019;15(5):1062-6.

12.Erel O, Neselioglu S. A novel and automated assay for thiol/disulphide homeostasis. Clin Biochem. 2014;47(18):326-32.

13.Relli V, Trerotola M, Guerra E, Alberti S. Abandoning the Notion of Non-Small Cell Lung Cancer. Trends in molecular medicine. 2019;25(7):585-94. 14.Lawless MW, O'Byrne KJ, Gray SG. Targeting oxidative stress in cancer. Expert Opin Ther Targets. 2010;14(11):1225-45.
15.Kryston TB, Georgiev AB, Pissis P, Georgakilas AG. Role of oxidative stress and DNA damage in human carcinogenesis. Mutat Res. 2011;711(1-2):193-201. 16.Penta JS, Johnson FM, Wachsman JT, Copeland WC. Mitochondrial DNA in human malignancy. Mutat Res. 2001;488(2):119-33.

17.Afonso V, Champy R, Mitrovic D, Collin P, Lomri A. Reactive oxygen species and superoxide dismutases: role in joint diseases. Joint Bone Spine. 2007;74(4):324-9. 18.Yanbaeva DG, Dentener MA, Creutzberg EC, Wesseling G, Wouters EF. Systemic effects of smoking. Chest. 2007;131(5):1557-66.

19. Wise SS, Holmes AL, Wise JP, Sr. Hexavalent chromium-induced DNA damage and repair mechanisms. Rev Environ Health. 2008;23(1):39-57.

20.Uzel Şener M SÖ, Keyf İA, et al. Evaluation of Thiol/Disulfide Homeostasis in Lung Cancer. Turk Thorac J 2019; DOI: 10.5152/TurkThoracJ.2019.19033. 21.Ates I, Kaplan M, Yuksel M, Mese D, Alisik M, Erel Ö, et al. Determination of thiol/disulphide homeostasis in type 1 diabetes mellitus and the factors associated with thiol oxidation. Endocrine. 2016;51(1):47-51. 22.Mengen E, Uçaktürk SA, Kocaay P, Kaymaz Ö, Neşelioğlu S, Erel Ö. The Significance of Thiol/Disulfide Homeostasis and Ischemia-modified Albumin Levels in Assessing Oxidative Stress in Obese Children and Adolescents. Journal of clinical research in pediatric endocrinology. 2020;12(1):45-54.

23.Altıparmak IH, Erkuş ME, Sezen H, Demirbag R, Gunebakmaz O, Kaya Z, et al. The relation of serum thiol levels and thiol/disulphide homeostasis with the severity of coronary artery disease. Kardiologia polska. 2016;74(11):1346-53.

24.Babaoglu E, Kilic H, Hezer H, Dag O, Parlak E, Senturk A, et al. Comparison of thiol/disulphide homeostasis parameters in patients with COPD, asthma and ACOS. European review for medical and pharmacological sciences. 2016;20(8):1537-43. 25.Ates I, Ozkayar N, Inan B, Yilmaz FM, Topcuoglu C, Neselioglu S, et al. Dynamic thiol/disulphide homeostasis in patients with newly diagnosed primary hypertension. Journal of the American Society of Hypertension : JASH. 2016;10(2):159-66. 